\title{
Improving the psychological well-being of prisoners through group counseling with Solution-Focused Brief Therapy (SFBT) approach
}

\author{
Ade Sucipto, ${ }^{1 *}$ Edy Purwanto, ${ }^{1}$ Muhammad Japar, ${ }^{2}$ Agnieszka Iłendo-Milewska ${ }^{3}$ \\ ${ }^{1}$ Postgraduate Program, Universitas Negeri Semarang, Semarang - Indonesia, ${ }^{2}$ Faculty of Teacher Training \\ and Education, Universitas Muhammadiyah Magelang, Magelang - Indonesia, ${ }^{3}$ Faculty of Psychology, \\ Private University in Bialystok, Bialystok - Poland
}

\begin{abstract}
Psychological well-being (PWB) is important for prisoners, considering that they lead different lives and become increasingly depressed by being labelled as criminals by society. This study aims to examine the effectiveness of group counseling using a Solution-Focused Brief Therapy (SFBT) approach to improve prisoners' PWB. A quasi-experimental design was employed, with repeated measurements (pre-test, posttest, and follow-up). The subjects were 14 Class II A prisoners in Pekalongan, Indonesia, prison, with seven inmates in the experimental group and seven in the control group. They were selected using the purposive sampling technique based on inclusion criteria and low PWB levels obtained from the psychological well-being scale. The study results indicate that group counseling using the SFBT approach is effective in increasing the PWB of prisoner's pre-test vs. post-test $(\mathrm{MD}=-64.857, \mathrm{SE}=3.749, \mathrm{p}<.05)$, and post-test vs. follow-up ( $\mathrm{MD}=-71.571, \mathrm{SE}=3.479, \mathrm{p}<.05)$. The study findings could be used as consideration, reference, and an alternative for counselors to use the SFBT approach in dealing with problems related to psychology, especially PWB.
\end{abstract}

Keywords: group counseling; solution-focused brief therapy (SFBT); psychological well-being; counselor; prisoners

\begin{abstract}
Abstrak: Psychological well-being (PWB) penting bagi narapidana mengingat narapidana mempunyai kehidupan yang berbeda dan semakin tertekan dengan adanya label penjahat dari masyarakat. Penelitian ini bertujuan untuk menguji efektifitas konseling kelompok dengan pendekatan Solution-Focused Brief Therapy (SFBT) untuk meningkatkan PWB narapidana. Penelitian ini menggunakan desain quasieksperimental dengan pengukuran berulang (pre-test, post-test, dan follow-up). Subjek merupakan narapidana Kelas II A LP Pekalongan yang berjumlah 14 orang (7 narapidana masuk kelompok eksperimen dan 7 narapidana masuk kelompok kontrol). Subjek dipilih menggunakan teknik purposive sampling dengan berlandasan pada kriteria inklusi dan tingkat PWB rendah yang diperoleh dari psychological well-being scale. Hasil penelitian ini menunjukan bahwa konseling kelompok dengan pendekatan SFBT terbukti efektif untuk meningkatkan PWB narapidana saat pre-test vs. post-test $(\mathrm{MD}=-64,857, \mathrm{SE}=3,749, \mathrm{p}<0,05)$, dan post-test vs. follow-up $(\mathrm{MD}=-71,571, \mathrm{SE}=$ $3,479, \mathrm{p}<0,05)$. Hasil penelitian ini dapat dijadikan sebagai pertimbangan, acuan dan alternatif konselor untuk menggunakan pendekatan SFBT dalam menangani masalah yang berkaitan dengan psikologi, khususnya PWB.
\end{abstract}

Kata Kunci: konseling kelompok; solution-focused brief therapy (SFBT); psychological well-being; konselor; narapidana *Corresponding Author: Ade Sucipto (adesucipto222@gmail.com). Pascasarjana Universitas Negeri Semarang, Jl Kelud Utara III,
Semarang 50237-Indonesia. 


\section{Introduction}

Prisoners live a different life from those who live a normal life. Hairina and Komalasari (2017), explain that prisoners living in a prison lead a life incomparable to that of individuals in general. The life in a prison poses particular limitations, such as the lack of freedom of choice, the lack of interaction with opposite sex, and the self development they can not progress to its optimum.

A prisoners' life induces problems such as health problems as well as non physical problems. Kosberg and ACSW (2008) explain that a prison life poses high risks to both physical and psychological health. The frequentlyoccurring physical problem is the inadequate nutrient in the food consumed daily, while the non physical problem being the lack of social support, low appraisal, and the inadequate facilities provided at the prison as well as the over occupancy of the prison due to the growing number of incoming new prisoners which affects the prisoners' comfort in serving their times (Saputra et al., 2018).

Adiansyah and Sukihananto (2017) explain that problems experienced by prisoners cause psychological impacts greater than the physical impacts. Serving prisoners who live in the prison shows the lack of enthusiasm in leading their lives, they are desperate and even suicidal. Shame, inferiority, pessimism, life without goals, and low appraisal pose constraints for the prisoners to comply with the process of edification (Bukhori, 2016; Hutapea, 2001). Ryff and Keyes (1995) explain that individuals with low psychological well-being usually suffer from lack of optimism in living their lives, desperation, life without goals, lack of confidence and negative judgement to themselves as well as other people.
Likewise, Mulyadi (2005) suggests that the life in the prison the life that takes away prisoners' individual freedom. Utami and Maskur (2019) explains that the taken away freedom manifest as the loss heterosexual relationship, the loss of autonomy, the loss of goods and service as well as the loss of security. Beside the taken away freedom, prisoners also suffer from negative attribution from the society (moral rejection of the inmates by the society).

During their service, prisoners suffer more pressure by the term "criminal" labelled onto them by the society. The label put onto them obviously has a negative connotation, and while it is stuck on them, it significantly affects the prisoners' psychological conditions (Martha \& Khoirunnas, 2018). Hairina and Komalasari (2017) state that numerous conditions taking place in the prison put the prisoners prone to psychological impacts. Symptoms commonly experienced by prisoners such as anxiety disorder and depression cause them to withdraw from social life. Such conditions cause the weakening psychological well-being of the prisoners. Prisoners with low psychological well-being will also suffer from lack of self confidence, bounded by anxiety felt by individuals, as well as negative attitude towards themselves and other people (Savitri \& Listiyandini, 2017). Consequently, prisoners find it hard to communicate with other people while having negative judgement on themselves and on others, and therefore inferiority emerges (Ryff \& Keyes, 1995).

Psychological well-being (PWB) is a condition existing in an individual. He conditions establish good communication with other people, has good self-control, is independent, has a, and in his life, and optimizes his strengths (Liwarti, 2013). Psychological well-being is a condition 
where an individual can establish a good relationship with other individuals, have purposes, good judgment of his past, and accept himself, both his weaknesses and strengths (Rahmawati, 2017).

Psychological well-being is essential for prisoners, considering that they live different lives from that people generally live. Direct observation by researchers at Class II Prison of Pekalongan City shows the fact that many prisoners suffer from introversion. The existing introvert attitude makes them withdraw themselves from communication with others and establish a relationship with fellow prisoners. Many prisoners suffer from great anxiety, lack of confidence as well as low appraisal toward themselves and their surroundings. The researchers' observation result is in line with the explanation from Mr. Boediono (Chief of Edification and Education Department, Class II Prison of Pekalongan City). Mr. Boediono explained that many prisoners look quiet isolate themselves while conducting daily activities, emotional and cranky, frequently cause commotions in the prison. Once in a while, prisoners burst into tears while talking about the past they have gone through (from 18 May 2020 interview). This indicates that the prisoners have low psychological well-being (Azani, 2012). Further, Karima et al. (2019) explain that prisoners expecting imminent release pose low psychological well-being. Low psychological wellbeing among prisoners is further discovered based on Hutapea (2001) research, which states that prisoners with low psychological well-being are greater in number than those with high psychological well-being.

Prisoners with low psychological well-being are described as having bad self-acceptance, bad relationship with other people, lack of independence and greatly dependent on other people in making decisions, not having a purpose in life and having low passion to explore their abilities and the potentials in themselves (Mardenny, 2017). Therefore, the prisoners' psychological well-being needs to be improved so that they will be able to return to the society with joy, positive perspective and able to develop the potentials they already have in them.

There had been researches attempting to improve psychological well-being, however the result was not effective enough, as Utami et al. (2016) state that intervention through positive psychotherapy groups turn out to be helpless in improving prisoners' psychological well-being narapidana. Likewise, Astuti and Setiyawati (2019) explain that after mindfulness-based intervention is given, the individuals did not show significance in psychological well-being improvement. Therefore, it requires an intervention that is effectively applicable for significantly improving individual psychological well-being. One type of intervention a counselor can effectively and efficiently conduct is the group counseling service applied through Solution-Focused Brief Therapy (SFBT) approach. SFBT has proven effective and efficient to improve psychological well-being (Bagajan et al., 2016; Bannink, 2007) The effectiveness of SFBT approach can be seen at the prisoners' optimistic facial expression and their focus towards the problems they are facing (Fitch et al., 2012). Besides, SFBT does not regard how much attending counseling process is done, but rather emphasizing on effective counseling by focusing on problem solving and setting the purposes an individual wishes to set.

SFBT is a therapeutic approach classified in post modern trend. This has been developed by two prominent figures namely Steve De Shazer 
and Insoo Kim Berg in late 1980. This approach's principle states that an individual possesses the strengths or potentials in him to solve a problem being faced. It is the strength within an individual which makes a counselee achieve the freedom to set the purposes he desires (Corey, 2016).

The brief therapy in SFBT is not one applied to speed up (a quick fix), instead one designed to help a counselee focus by implementing a treatment (intervention short-term). Intervention short-term aims at directing a counselee to manage what he is supposed do next or for a better future (Davis \& Osborn, 2000; Mulawarman, 2019). SFBT approach is proven effective for handling psychological problems, as Agustin (2012) explains that SFBT approach is significantly effective to reduce quarterlife crisis on an individual.

Based on SFBT evidence, group counseling offers more advantages when SFBT approach is applied. Through group counseling intervention, a counselee has the opportunity to carry out a therapeutic process with fellow group members to create an optimistic atmosphere to motivate healing (Gladding, 2012). Here group counseling refers to an interpersonal communication process between the counselor or psychological professional with individuals and the problems each faces (Corey, 2016; Gibson \& Mitchell, 2011; Wibowo, 2005). The other advantage is emphasizing a more effective and efficient counseling process, considering SFBT focuses more on solving a problem being faced.

Therefore, the hypothesis proposed in this research is group counseling by applying the thesis solution-focused brief therapy (SFBT) approach, which effectively improves the prisoners' psychological well-being. Specifically, this research applies SFBT approaches. The application of such an approach helps the prisoners realize their negative perceptions so that they can evaluate the negative thoughts and eventually transform them into positive perceptions. Besides, a counseling with SFBT approach can help an individual be aware of the present reality, be motivated to stay optimistic about his future, shape the goals he sets and help him realize that communication with other people is very important. SFBT is proven effective in dealing with problems related to the psychological contexts of school students and university students(Fernando \& Rahman, 2018; Hendar et al., 2020; Novriansyah et al., 2019). Direct counseling to prisoners or special populations will add a new spectrum into Indonesia's counseling world. In reality, Indonesia's counseling practices have so far reached as far as formal education sectors, hence it is rare to find a counseling practice among special populations, such as prisoners. This research is hoped to empower counseling practices to be limited in education sectors only.

\section{Method}

This research uses group counseling with solution-focused brief therapy (SFBT) approach as an independent variable and psychological well-being as a dependent variable. The research design used is quasi-experimental with threetime measuring: pre-test, post-test, and follow-up (Creswell, 2015). Pre-test is carried out by distributing psychological well-being instrument before group counseling intervention is applied with SFBT approach. Intervention is conducted in 5 sessions, 100 minutes each. Post-test is the step when psychological well-being instrument is given back after intervention is added. Follow-up is when psychological well-being instrument is 
given back after 14 days since post-test is conducted.

The subjects of the research are the prisoners of Class II A Prison of Pekalongan City which has low psychological well-being level. The research subjects consist of 14 prisoners distributed into 2 groups where 7 prisoners are in experiment group while the other 7 are in control group. The subjects have been selected through purposive sampling (non random) technique, based on the inclusion and psychological well-being level of the prisoners. The psychological well-being level of the prisoners is detected through the psychological well-being scale, where the result is used as pretest. The pre-test is aimed at figuring out the prisoners' psychological well-being before they receive intervention and the pre-test result, to be compared to the post-test and follow-up result. The inclusion criteria as summarized by Table 1 .

The instrument in this research is one in the form of psychological scale. The instrument used is the psychological well-being instrument by Ryff (1989). In the psychological well-being developed by Ryff, there are 7 response alternatives or answers, namely totally agree with the statement (SS) $=7$, agree with the statement $(S)=6$, quite agree with the statement
$(\mathrm{CS})=5$, neutral to the statement $(\mathrm{N})=4$, quite disagree with the statement (CTS) $=3$, disagree with the statement (TS) $=2$ and totally disagree with the statement (STS) $=1$ for each favorable questions dan unfavorable questions respectively.

The instrument has been adapted in this research. The instrument adaptation examination used is the scientific process to adjust the original to its adaptation version's language transformation. The adaptation does bot merely cover language aspects but also other aspects such as psychometrical characteristics as well as cultural characteristics (Iliescu, 2017).

In conducting the instrument adaptation in this research, a concept from (Lenz et al, 2017) was adapted regarding translation and crosscultural adaptation of assessments for counseling research. The adaptation technique applied was translate and back translate. Translate is the step of instrument adaptation examination where the researcher translates the instrument to the Indonesian language. Back translate is the step of instrument adaptation examination where the Indonesian translation is translated back to the original instrument's language. Black translate plays an important role in the instrument

Table 1

Inclusion Criteria

\begin{tabular}{cll}
\hline No. & Inclusion Group & Exlusion Group \\
\hline 1 & $\begin{array}{l}\text { Prisoners of Class II A Prison of Pekalongan } \\
\text { City who are in their assimilation period } \\
\text { (serving time remains less than 5 months) } \\
\text { Prisoners having the psychological well-being } \\
\text { score level of }<152\end{array}$ & $\begin{array}{l}\text { Prisoners of Class II A prison of Pekalongan City } \\
\text { whose remaining serving time is less than } 5 \\
\text { months } \\
\text { Prisoners having the psychological well-being } \\
\text { score level of }>152\end{array}$ \\
& $\begin{array}{l}\text { Prisoners willing to comply or join the } \\
\text { research groups and sign the agreement letter. }\end{array}$ & $\begin{array}{l}\text { Prisoners who are not willing to comply nor join } \\
\text { the research group and hence do not sign the } \\
\text { agreement letter. }\end{array}$ \\
\hline
\end{tabular}


adaptation examination. Back translation can reveal translation mistakes and failures in adapting the translation result to the research subject's language and culture (Lenz et al, 2017).

When the adaptation process is over, the instrument is consulted to an expert to confirm, evaluate the content of the instrument and, observe the cultural conformity. When this is over, the next step is examining the instrument and its psychological well-being to the prisoners. The validity examination and instrument reliability use Product Moment Pearson correlation with the help of SPSS 25 (statistical product and service solutions 25). An item is declared valid when the correlation score is above .3 (Azwar, 2017). The reliability examines overviews cronbach alpha values, with the minimum of .05. The instrument examination result is declared valid when the lowest score is 0.306 and the highest is .626. Cronbach's alpha score is .731. From the examination result a conclusion is drawn that the psychological wellbeing instrument is valid and reliable, therefore the instrument is credible for use.

The data analysis technique applied in the research is the one-way analysis of variance (ANOVA) repeated measures with SPSS 25. This data analysis technique aims to examine if the study's hypothesis, namely group counseling with solution-focused brief therapy (SFBT) approach, effectively improves psychological well-being.

\section{Results}

The prisoners with low psychological wellbeing scores are divided into two groups, 7 in the experiment group and 7 in the control group. The intervention was applied to both the experi- mental and control group. The pre-test outcomes, post-test, and follow-ups on the experimental and control groups are presented in Table 2.

Table 2 is the pre-test, post-test score result and psychological well-being instrument follow up on the experiment group and control group. The researcher did this to figure out the intervention's effectiveness and see the increase in psychological well-being at each stage.

Based on data summarized in Table 3, the mean psychological well-being score on the pretest result of the experiment group is 140.29 with the SD of 6.921. After the intervention is given, the experiment group's psychological well-being level increases from the mean of 140.29 to 205.14 and 276.71 (post-test and follow-up) with the SD of 7.105 and 5.851. Therefore, the experiment group's psychological well-being level improves, as evidenced by the pre-test scores, post-test, and follow-up.

The mean psychological well-being mean score on the control group's pre-test result is 141.71 with the SD of 5.851. After intervention is given, the control group's psychological well-being level increases from the mean of 141.71 to 190.86 and 215.29 (post-test and follow-up) with the SD of 10.72 and 6.676. Therefore, the control group's psychological well-being level improves, as evidenced by the pre-test scores, post-test, and follow-up. Thus, the intervention given to both groups can improve prisoners' psychological wellbeing.

The pairwise (comparison) analysis result shows the pre-test score, post-test, and follow-up measuring of both experiment and control groups. The improvement score of the experiment group and control group at the pre- 
Table 2

Pre-test, Post-test Score Distribution and Psychological Well-being instrument Follow up

\begin{tabular}{|c|c|c|c|c|c|c|c|}
\hline \multicolumn{4}{|c|}{ Experiment Group } & \multicolumn{4}{|c|}{ Control Group } \\
\hline Subject & Pre-test & $\begin{array}{l}\text { Post- } \\
\text { test }\end{array}$ & Follow-Up & Subject & Pre-test & $\begin{array}{l}\text { Post- } \\
\text { test }\end{array}$ & $\begin{array}{l}\text { Follow- } \\
\text { Up }\end{array}$ \\
\hline & 137 & 196 & 271 & & 144 & 196 & 215 \\
\hline & 149 & 200 & 269 & & 134 & 199 & 212 \\
\hline & 142 & 210 & 281 & & 134 & 174 & 220 \\
\hline & 130 & 205 & 277 & & 142 & 188 & 207 \\
\hline & 134 & 199 & 273 & & 143 & 192 & 216 \\
\hline & 143 & 215 & 282 & & 150 & 204 & 227 \\
\hline & 147 & 211 & 284 & & 145 & 183 & 210 \\
\hline
\end{tabular}

Table 3

Pre-test, Post-test Distribution Tabulation and Psychological Well-Being Instrument Follow-up

\begin{tabular}{lllll}
\hline & \multicolumn{2}{l}{ Experiment Group } & \multicolumn{2}{l}{ Control Group } \\
\cline { 2 - 5 } & Mean & $\begin{array}{l}\text { Deviation Standard } \\
\text { (SD) }\end{array}$ & Mean & $\begin{array}{l}\text { Deviation Standard } \\
\text { (SD) }\end{array}$ \\
\hline Pre-test & 140.29 & 6.921 & 141.71 & 5.851 \\
Post-test & 205.14 & 7.105 & 190.86 & 10.72 \\
Follow-up & 276.71 & 5.851 & 215.29 & 6.676 \\
\hline
\end{tabular}

Table 4

Pairwise Comparisons Result

\begin{tabular}{lllll}
\hline \multirow{2}{*}{ Group } & Test & MD & SE & P \\
\hline \multirow{2}{*}{ Experiment } & T1-T2 & -64.857 & 3.749 & .000 \\
& T2-T3 & -71.571 & 3.479 & .000 \\
\multirow{2}{*}{ Control } & T1-T2 & -49.143 & 4.435 & .000 \\
& T2-T3 & -24.429 & 4.599 & .000 \\
\hline \multicolumn{2}{l}{ Note: MD (Mean difference), SE (std. Error difference), P (Probability) }
\end{tabular}

test measuring against post-test (T1-T2) shows the score of $\mathrm{MD}=-64.857, \mathrm{SE}=3.749, \mathrm{P}<.05$ and at the post-test measuring against follow-up (T2T3) shows the score of $\mathrm{MD}=-71.571, \mathrm{SE}=3.479$, $\mathrm{P}<.05$. At the pre-test measuring against posttest (T1-T2), the control group shows the score of $\mathrm{MD}=-49.143, \mathrm{SE}=4.435, \mathrm{P}<.05$ and at the posttest measuring against follow-up (T2-T3) shows the score of $\mathrm{MD}-24.429, \mathrm{SE}=4.599, \mathrm{P}<.05$. Therefore, both the experimental group and control group can improve their psychological well-being. The comparison results in a discussion is presented in Table 4.

Based on Table 4 and Figure 1, it is known that both the experiment group and control group can improve their psychological wellbeing. The intervention given to both groups help improve the prisoners' psychological well-being. However, the experiment group has a greater MD score than the control group. From here it is 
concluded that group counseling with SolutionFocused Brief Therapy (SFBT) approach is more effective for improving the psychological wellbeing of the prisoners of Class II A Pekalongan City prison.

\section{Discussion}

The research result suggests that SolutionFocused Brief Therapy (SFBT) is effective for improving psychological well-being. This result is in line with that of Bagajan (2016), which states that there is an increase in the mean score of an individual's psychological well-being after following the intervention using SolutionFocused Brief Therapy (SFBT) approach. The improvement of psychological well being among the group members enables them to achieve their desired purposes, establishing good relationship with other people, able to accept their own conditions and have a good appraisal on themselves as well as others. Lee et al. (2007) explains that this approach encourages the counselees to intensively participate in following the intervention given, so that they may be able to set and express their desired purposes. This research result supports the research conducted by Grant (2003) which states that individuals experience significant improvement in achieving their life purposes and psychological quality after participating in the therapy sessions where solution focused approach is applied. Besides, the significant improvement in individuals takes place in all psychological well-being dimensions (Green et al., 2006).

Further, it is in line with the counseling concept that the core of counseling is a quest for solution. Hanifa et al. (2019) state it is common that a number of counselees come with the purpose to seek solution for the problems they are facing. Group counseling with SFBT approach is an approach applied in a counseling process which is simple and easy for implementation because it focuses more on how to find a solution for a problem being faced (Rusandi \& Rachman,

Figure 1

Estimated Marginal Means

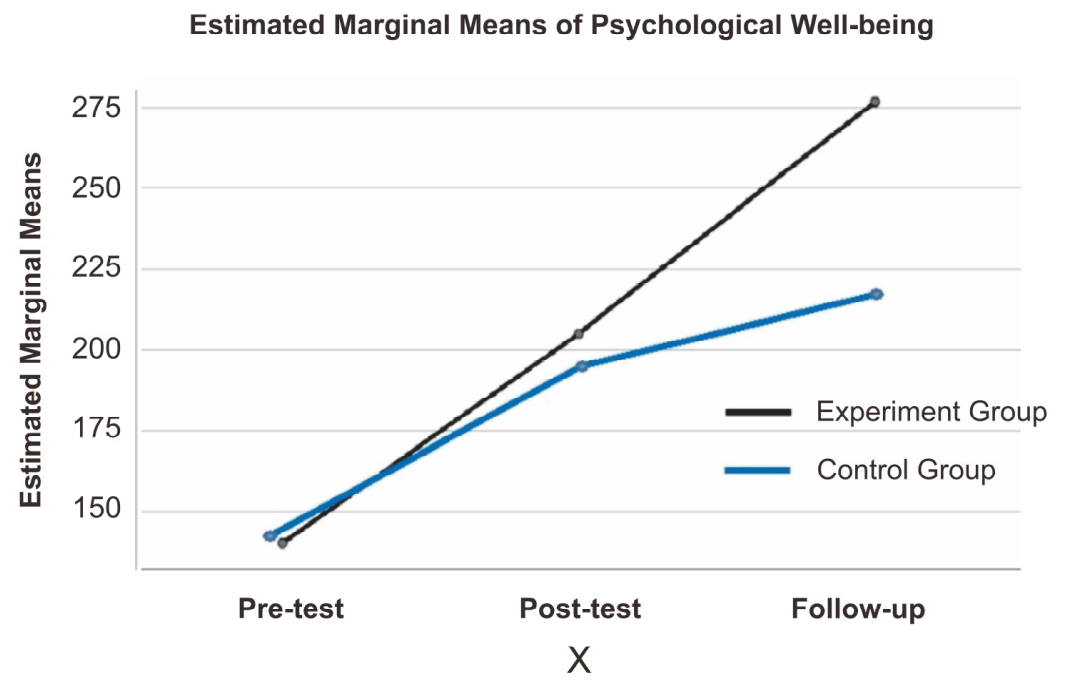


2014). A counselor can utilize group counseling with SFBT approach as an alternative way of effectively and efficiently administering the counseling sessions.

The pre-test, post-test, and follow-up process using the IBM SPSS 25 program shows that group counseling with SFBT approach can effectively improve prisoners' psychological wellbeing. The result is in line with the explanation from Mr. Boediono (Chief of Community Edification Department Pekalongan City prison) in which he states that a significant change took place among prisoners who have attended counseling process. The change is visible that the prisoners can socialize with other fellow prisoners, willing to actively get involved in activities held by the prison management and are more enthusiastic attending mosque activities (based on interview, 4 July 2020). This is in compliance with the research conducted by (Bagajan et al., 2016) which states that SFBT approach can improve psychological well-being. Besides, SFBT can effectively and efficiently improve self intelligence, life purposes, self development, dominance towards the surroudings, self control and harmonious communication as well as improvement of psychological well-being (Bannink, 2007).

Group counseling applying Solution-Focused Brief Therapy (SFBT) approach is proven effective for improving psychological well-being because there is principal similarity. Such similarity can link the psychological well-being after intervention is given. SFBT focuses on problem solving and set the goals desired by an individual (Fitch et al., 2012). In agreement with Fitch et al. (2012), Mulawarman (2019) it is explained that Solution-Focused Brief Therapy does not regard how many sessions are attended during the counseling stage, instead it emphasizes on the effective counseling process by focusing on the expected solution for the problems being faced, while setting goals and how an individual has to carry them out to finally achieve the goals.

The solution-focused brief therapy (SFBT) concept focuses on the solution, the purpose, and how to achieve it. It is in agreement with one of the indicators of psychological well-being. Ryff and Keyes (1995) explain that psychological well-being consists of five dimensions in an individual required for dealing with problems, so that the individual may function fully and positively. The five dimensions are namely achieving the purpose of life, independence, self growth, good relationship and self acceptance. Conforming to this, the research of Ariyanti et al. (2020) state that Solution-Focused Brief Therapy (SFBT) approach can effectively improve an individual's ability in determining his own purposes as he desires them.

One of the dimensions in psychological wellbeing is achieving the purpose of life. Purpose of life is an individual goal to function throughout his life fully. An individual who is confident that he is useful means he can plan and set his purposes, ideals, targets and he is confident that his past life and future life are meaningful (Keyes, 2000). An individual without purposes in his life and does not set targets to achieve means he has a meaningless life. On the other hand, an individual who has the dimension of low purpose of life will lose his purposes, targets, and meaning of his life while lack of passion or confidence that otherwise will be meaningful for his life (Ryff, 1995). The dimension in psychological well- 
being namely dimension of purpose of life is similar to Solution-Focused Brief Therapy which focuses on purpose of life and how to achieve them. Such similarity can link psychological wellbeing after participating in the counseling process and applying solution-focused brief therapy approaches.

Counseling applying solution-focused brief therapy (SFBT) approach principally directs counselees to have positive perspective towards the problems being faced. Dejong and Berg (2008) explain that the principle of SFBT believes that inside an individual there is the potential for behaving effectively in solving a problem he is facing, however this potential is usually buried under negative assumptions. SFBT directs an individual to pay more attention to his potentials and resources. He already has to construct a solution rather than focus on a problem of a failure that has already happened (Shazer \& Dolan, 2007). According to the research result of Hendar et al. (2020), it is stated that group counseling applying SFBT approach can improve confidence and potentials solve problems being faced.

SFBT approach is an approach with positive atmosphere, adorned with hopes and focuses on the desired future. Misconception in defining meanings should be amended so that the counselee will be able to break out of the problem he is facing. As Selekman (2005) explained, positive thinking and optimism speeds up psychological improvement as opposed to what negative thinking and pessimism can do. Therefore, an individual who has a problem in recognizing meanings of life must be given intervention through a group counseling where SFBT approach is implemented. In their research,
Gingerich and Eisengart (2000) explain that SFBT approach can be effective and efficient in transforming an individual's judgment on both himself and other people.

Therefore, based on the above-mentioned explanation, it can be concluded that if a SolutionFocused Brief Therapy (SFBT) session focuses on setting purpose of life and how to achieve them, it can indirectly improve psychological well-being in an individual. The research by Carr et al. (2013) exposes that an individual's intervention through SFBT approach can effectively and efficiently improve his psychological welfare. Based on this, it can be concluded that group counseling through SFBT approach effectively improves psychological well-being.

\section{Conclusion}

The application of group counseling with Solution-Focused Brief Therapy (SFBT) approach is effective for improving psychological wellbeing of the prisoners of Class II A Prison of Pekalongan City. The result of this research can be used as a reference for counsellors and may serve as a solution alternative to help solve the problems faced by counselees, especially problems related to psychological well-being. Further, the findings throughout the research opens a new perspective for Indonesian counsellors, that group counseling services are effective not only at educational institutions but also for implementation at special population such as prisoners.

This research suggests active intervention to experiment group and control group. The next researchers should add placebo groups into the experiment's research design. A placebo group will turn important to ensure that the experiment 
group's intervention will be firmer and stronger to improve the dependent variables. However, this research is limited to focusing on the prisoners' psychological well-being. Other than this, the prisoners need to improve their self- regulation and career planning to later on meet their own lives' needs after their discharge from the prison. Therefore, the next research is advised to apply SFBT approach to improve the prisoner's self-regulation and career planning.[]

\section{References}

Adiansyah, A., \& Sukihananto, S. (2017). Kekerasan fisik dan psikologis pada narapidana lansia di lembaga pemasyarakatan Jawa Barat. Jurnal Keperawatan Indonesia, 20(3), 168-175. https://doi.org/10.7454/jki.v20i3.623

Agustin. (2012). Terapi dengan pendekatan solution focused pada individu yang mengalami quarter life crisis. Fakultas Psikologi Universitas Indonesia.

Ariyanti, N. M. P., Hamidah, H., \& Widiasavitri, P. N. (2020). Terapi singkat berfokus solusi untuk meningkatkan kemampuan penetapan tujuan pada narapidana yang menjelang bebas di lembaga pemasyarakatan. Psycho Idea, 18(1), 16-25. https://doi.org/10.30595/psychoidea.v18i1.5919

Astuti, N. B., \& Setiyawati, D. (2019). Program intervensi berbasis mindfulness untuk meningkatkan kesejahteraan psikologis caregiver pasien kanker anak. Gadjah Mada Journal of Professional Psychology (GamaJPP), 3(2), 109-122. https://doi.org/10.22146/gamajpp.43407

Azani. (2012). Gambaran psychological well-being mantan narapidana. Empathy: Jurnal Fakultas Psikologi, 1(1).

Azwar, S. (2017). Metode penelitian psikologi. Pustaka Pelajar.

Bagajan, K. Q., Osman, K., Ziba, M. C., \& Majid, C. (2016). The impact of Solution-Focused Brief Therapy on the improvement of the psychological wellbeing of family supervisor women. International Journal of Pscychological and Behavioral Sciences, 10(1), 296-300. https://doi.org/10.5281/zenodo.1338943

Bannink, F. P. (2007). Solution-focused brief therapy. Journal of Contemporary Psychotherapy, 37(2), 8794. https://doi.org/10.1007/s10879-006-9040-y

Bukhori, B. (2016). Pengembangan social skill narapidana melalui pelatihan pijat. Dimas: Jurnal $\begin{array}{lllll}\text { Pemikiran Agama } & \text { Pntuk }\end{array}$ https://doi.org/10.21580/dms.2016.161.891

Corey, G. (2016). Theory and practice of counseling and psyhotherapy (10th editi). Brooks/Cole.

Creswell, J. W. (2015). Riset pendidikan: Perencanaan, pelaksanaan, dan evaluasi riset kualitatif \& kuantitatif. Pustaka Pelajar.

Davis, T. E., \& Osborn, C. J. (2000). The solution-focused school counselor: shaping professional practice. Philadelphia: Accelerated Development.

Fernando, F., \& Rahman, I. K. (2018). Efektifitas solution focused brief therapy (SFBT) islami guna meningkatkan regulasi diri mahasiswa yang mengalami prokrastinasi. Journal of Innovative Counseling: Theory, Practice \& Research, 2(2), 16-31. 
Fitch, T., Marshall, J., \& McCarthy, W. (2012). The effect of solution-focused groups on self-regulated learning. Journal of College Student Development, 53(4), 586-595. https://doi.org/10.1353/csd.2012.0049

Gibson, R. L., \& Mitchell, M. H. (2011). Bimbingan dan Konseling (7th ed.). Pustaka Pelajar.

Gingerich, W. J., \& Eisengart, S. (2000). Solution-focused brief therapy: A review of the outcome research. Family Process, 39(4), 477-498. https://doi.org/10.1111/j.1545-5300.2000.39408.x

Gladding, S. T. (2012). Konseling profesi yang menyeluruh. Indeks.

Grant, A. M. (2003). The impact of life coaching on goal attainment, metacognition and mental health. Social Behavior and Personality, 31(3), 253-263. https://doi.org/10.2224/sbp.2003.31.3.253

Green, L. S., Oades, L. G., \& Grant, A. M. (2006). Cognitive-behavioral, solution-focused life coaching: Enhancing goal striving, well-being, and hope. The Journal of Positive Psychology, 1(3), 142-149. https://doi.org/10.1080/17439760600619849

Hairina, Y., \& Komalasari, S. (2017). Kondisi psikologis narapidana narkotika di Lembaga Pemasyarakatan Narkotika Klas II Karang Intan, Martapura, Kalimantan Selatan. Jurnal Studia Insania, 5(1), 94. https://doi.org/10.18592/jsi.v5i1.1353

Hanifa, H. P., Kusumaningtyas, R., \& Arvianto, R. Y. (2019). Pelaksanaan layanan konseling berbasis biro (Studi deskriptif pada biro konseling Edupotensia Foundation Bandung).Jurnal Bimbingan Dan Konseling Ar-Rahman, 5(1), 36-42. https://doi.org/10.31602/jbkr.v5i1.1835

Hendar, K., Awalya, A., \& Sunawan, S. (2020). Solution-focused brief therapy group counseling to increase academic resilience and self-efficacy. Jurnal Bimbingan Konseling, 9(1), 1-7.

Hutapea, B. (2001). Terpenjara dan bahagia? Psychological well-being pada narapidana ditinjau dari karakteristik kepribadian. Proceding Pesat (Psikologi, Ekonomi, Sastra, Arsitektur, Dan Sipil), 4, 143-149.

Iliescu, D. (2017). Adapting tests in linguistic and cultural contexts. Cambridge University Press.

Karima, D., Siswadi, A. G. P., \& Abidin, Z. (2019). Psychological well-being warga binaan Lapas Wanita Kelas IIA Sukamiskin Bandung menjelang pembebasan. Persona:Jurnal Psikologi Indonesia, 8(1), 113-127. https://doi.org/10.30996/persona.v811.2378

Keyes, C. L. M. (2000). Subjective change and its consequences for emotional well-being. Motivation and Emotion, 24(2), 67-84. https://doi.org/10.1023/A:1005659114155

Kosberg, J. I., \& ACSW. (2008). The abuse of elderly men. Journal of Elder Abuse \& Neglect, 9(3), 69-88. https://doi.org/10.1300/J084v09n03_04

Lee, M., Sebold, J., \& Uken, A. (2007). Role of self-determined goals in predicting recidivism in domestic violence offenders. Research on Social Work Practice, 17(1), 30-41. https://doi.org/1049731506294375

Lenz et al. (2017). Translation and cross-cultural adaptation of assessments for use in counseling research. Measurement and Evaluation in Counseling and Development, 50(4), 224-231. https://doi.org/10.1080/07481756.2017.1320947

Liwarti, L. (2013). Hubungan pengalaman spiritual dengan psychological well being pada penghuni lembaga pemasyarakatan. Jurnal Sains Dan Praktik Psikologi, 1(1), 77-88.

Mardenny, M. (2017). Gambaran psychological well being narapidana kasus pembunuhan. Jurnal AlQalb, 8(1), 1-7.https://doi.org/10.15548/alqalb.v8i1.864 
Martha, A. E., \& Khoirunnas, C. (2018). Penganiayaan terhadap narapidana pelaku perkosaan yang mengalami label negatif di lembaga pemasyarakatan (Studi di Lembaga Pemasyarakatan Wirogunan Yogyakarta). Veritas et Justitia, 4(2), 388-421. https://doi.org/10.25123/vej.3064

Mulawarman, M. (2019). Solution focused brief counseling (Konsep, riset dan prosedur). Prenada Media Group.

Mulyadi, L. (2005). Pengadilan anak di Indonesia: Teori, praktik dan permasalahannya. Mandar Maju.

Novriansyah, D., Purwanto, E., \& Wibowo, M. E. (2019). The effectiveness of solution-focused brief therapy group counseling to improve students' self-concepts. Jurnal Bimbingan Konseling, 8(4), 130-136.

Rahmawati, I. (2017). Nilai sense of community pada kesejahteraan psikologis dalam menghuni (Housing Well-being): Studi meta-analisis. Psikohumaniora: Jurnal Penelitian Psikologi, 2(1), 81-93. https://doi.org/10.21580/pjpp.v2i1.952

Rusandi, M. A., \& Rachman, A. (2014). Efektifitas konseling singkat berfokus solusi (Solution Focused Brief Therapy) untuk meningkatkan self esteem mahasiswa program studi bimbingan konseling FKIP Unlam Banjarmasin. Al 'Ulum, 62(4), 22-26.

Ryff, C. D. (1989). Happiness is everything, or is it? Explorations on the meaning of psychological wellbeing. Journal of Personality and Social Psychology, 57(6), 1069-1081. https://doi.org/10.1037/0022-3514.57.6.1069

Ryff, C. D. (1995). Psychological well-being in adult life. Current Directions in Psychological Science, 4(4), 99-104. https://doi.org/10.1111/1467-8721.ep10772395

Ryff, C. D., \& Keyes, C. L. M. (1995). The structure of psychological well-being revisited. Journal of Personality and Social Psychology, 69(4), 719-727. https://doi.org/10.1037/00223514.69.4.719

Saputra, W. N. E., Da Costa, A., \& Alhadi, S. (2018). Creative Solution Focused Counseling Models (CSFCM): Strategi kreatif untuk mengembangkan self-regulated learning siswa. Jurnal Kajian Bimbingan dan Konseling, 3(4), 162-170. https://doi.org/10.17977/um001v3i42018p162

Savitri, W. C., \& Listiyandini, R. A. (2017). Mindfulness dan kesejahteraan psikologis pada remaja. Psikohumaniora: Jurnal Penelitian Psikologi, 2(1), 43. https://doi.org/10.21580/pjpp.v2i1.1323

Shazer, S. d., \& Dolan, Y. (2007). More than miracles: The state of the art of solution-focused brief therapy. The Haworth Press.

Utami, E. L., \& Masykur, A. M. (2019). Pengalaman proses menuju resiliensi pada terpidana kasus narkotika. Jurnal Empati, 8(4), 133-147.

Utami, N., Rachmah, N., \& Purwandari, E. (2016). Efektifitas kelompok psikoterapi positif untuk meningkatkan kesejahteraan psikologis pada narapidana. Universitas Muhammadiyah Surakarta.

Wibowo, M. E. (2005). Konseling kelompok perkembangan. Unnes Press. 
This page has been intentinally left blank. 